\title{
Yole!Africa: Negotiating Art and War in the East of Congo
}

Chérie Rivers Ndaliko, University of North Carolina at Chapel Hill

On July, 2012 more than 6,000 spectators gathered in the open-air cercle sportif stadium in Goma, east of the Democratic Republic of the Congo, to cheer the dance routines and vocal feats of the youth from around North Kivu province. The event uniting this crowd was a high point in the seventh edition of the Salaam Kivu International Film Festival (SKIFF), organized annually by the Yole!Africa cultural center. ${ }^{1}$ As the youth battled for the title of "Best Dance Group 2012," many of their choreographies depicted war and displacement.

Simultaneously, the rebel army known as the M23 had advanced within $30 \mathrm{~km}$ of Goma in its efforts to secure control of North Kivu. Thus, the steady stream of military helicopters circling the city as President Joseph Kabila deployed his special forces to fortify the dwindling national army lent the choreographed narratives an uncanny air of realism. The audience also was acutely aware that the danced re-enactments of violence presented by the youth were not only an imagined re-creation of war, but also choreographically embodied the events taking place directly outside the city. This performance drew a crowd significantly larger than even the masses of students and other protesters who clashed with police in downtown Goma.

Such a public turnout for artistic festivities in the midst of military mobilization reflects the growing influence of SKIFF in North Kivu. More than that, it underlines the strengths and the mission articulated by SKIFF's organizers, Yole!Africa. Yole!Africa's objectives - gathering and focusing the community toward more creative, nonviolent and democratic ends - has impacted the local community profoundly in its first decade of activity. Yole!Africa's activities have always tied the creative to the political. Many of its earlier projects involved describing and imagining a future based on an examination of recent political history (as seen in its arts festival 2010), then exploring the relationship between individuals, civil society initiatives and democracy in 2011. The 2012 theme, Ni Wakati (The Time is Now!), catalyzed a vibrant debate amongst the participants, more than 14,000 spectators and the wider radio and television audience about the power of individual and collective agency. This debate centered around the immediate choices facing the local community and its civil society initiatives, and the specific ways that youth can contribute to realizing their vision of the future through creative expression - from installations aiming to raise awareness to more radical artistic protests in collaboration with international peers.

Yole!Africa was founded in Goma in October 2002 following a series of violent conflicts (discussed below) and Laurent Kabila's rise to the presidency and subsequent assassination. Goma is the capital of North Kivu, the particularly volatile and mineral-rich region in the east of the DRC. Its founder, Petna Ndaliko Katondolo, elected to establish a cultural center at a moment when all "nonessential" organizations had been forcibly shut down and foreign personnel evacuated, which points to a radical creative and political ideology. The subsequent successes of Yole!Africa as an arts platform provides a compelling case through 


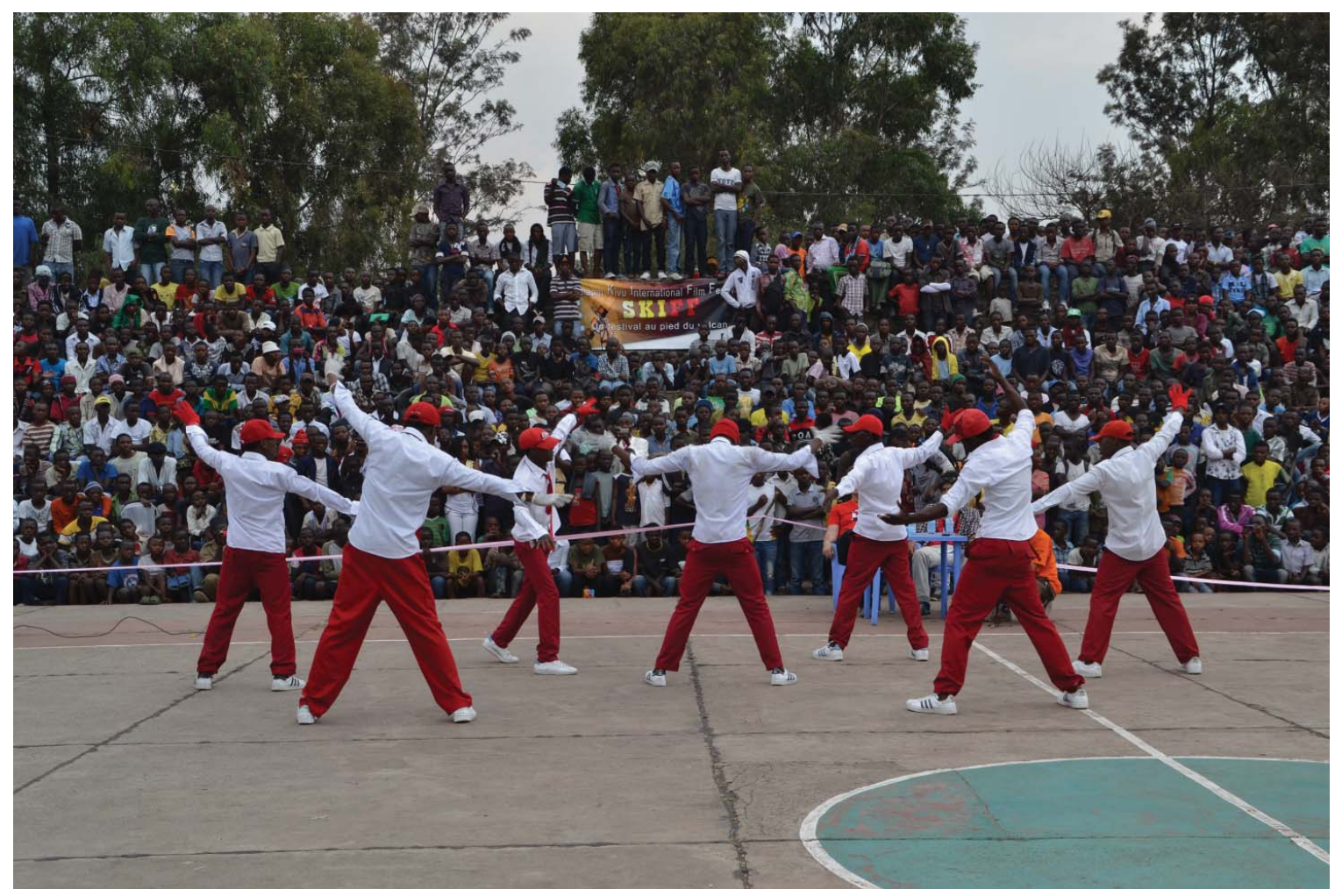

Figure 1. SKIFF 2012 Dance Competition.

Courtesy of Alkebu Film Productions.

Permission to publish granted by Alkebu Film Productions.

which to examine the power of individuals to catalyze an increasingly cohesive civil society movement around expressive culture in the face of conflict. $^{2}$

Since 2002, Yole!Africa has worked to mobilize its community in North Kivu, and particularly to empower the younger generation and women, whose presence and voice are often unrepresented in public fora. This form of social intervention is key in a system as corrupt as that which currently controls the east of the DRC. It hopes to shift the collective understanding of the relationship between sociopolitical cause and effect from one that is determined by fixed monolithic power structures to one that is malleable through the intervention of civil society.

This essay examines the implications and effects of Yole!Africa as a radical artistic intervention in the Congo conflict. As current co-director of the organization, I describe here the specific objectives of Yole!Africa in the midst of its present activities. I draw attention to the particular connections between expressive and artistic practices, civil society and activism against a backdrop of definitive global economic interests dominating the scene in the east of Congo. I discuss these factors in terms of the organization's progression of creative and civil society initiatives: its impetus 
and founding, the creation of SKIFF, the implementation of the regional NYAVU network and the Jazz Mama Movement.

Inherent to any discussion of the DRC are tensions that exist between Congolese provinces. These are the result of a confluence of historic and economic forces, complicated by the fact that many of the coveted natural mineral resources are found in the east of the country, while the seat of power remains fixed in the west. Furthermore, the sheer size and lack of internal infrastructure in DRC prevent easy administration of the nation. ${ }^{3}$

While much of this tension plays out in the political realm, it nevertheless has a significant impact on issues of culture production as well. To this end it is important to note that, despite their prescribed Congolese national identity, in cultural terms many of the populations in the east of Congo identify more with the Great Lakes region than with central Africa or the distant capital city, Kinshasa. Kiswahili is prevalent in the east of Congo and connects the Great Lakes region linguistically; further, travel to Uganda, Rwanda, Burundi and Kenya is more affordable and available compared with that to Kinshasa, ${ }^{4}$ contributing to regional exchange with other Great Lakes nations.

Thus, the vibrant cultural scene in Kinshasa has little regular impact on the east and no continuity in terms of programming or financial support. ${ }^{5}$ Whereas in Kinshasa there are a growing number of foreign entities dedicated primarily to cultural activities, ${ }^{6}$ the benefits of such project rarely extend beyond the capital province. In the east of Congo, foreign organizations incorporating cultural activities into their programming are generally humanitarian organizations whose engagement with expressive practice is only tangential to their primary operational objectives. ${ }^{7}$ Consequently, a significant portion of the local population views such cultural activities with suspicion. Furthermore, to the extent that humanitarian organizations do venture into the cultural sphere, such endeavors often come with monetary incentives that ultimately threaten rather than strengthen the tenuous local artistic economy.

Thus this presentation of Yole!Africa's activity in the east of Congo is specific to the dynamics embedded in local history and geography. That is to say, this analysis of the organization's radicalism is framed in terms of the surrounding ethos of humanitarianism, and the described distinctions between governmental and independent interventions are specific to the east rather than being representative of the nation as a whole.

\section{The EARLy Years (2002-2006)}

In 2002, the east of Congo was the scene of a series of violent conflicts, outlined only briefly here. ${ }^{8}$ The First Congo War (August 1996 to May 1997) erupted in the aftermath of the Rwandan Genocide and was fueled by global economic demand for mineral resources, particularly coltan. ${ }^{9}$ This conflict coincided with the rebel movement led by Laurent Kabila, who overthrew dictator Mobutu Sese Seko in 1997 and became president; it also catalyzed a long series of events that would plague Kivu, among them invasions from neighboring Rwanda and Uganda, the illicit extraction of lucrative natural resources, and the forced conscription of child soldiers. Although this war officially ended in 1997, the violence in the east of Congo never subsided. Indeed, while a political struggle played out in Kinshasa as Kabila attempted to take control of the nation, the east of Congo saw repeated invasions by neighboring rebel armies, the plundering of its resources, and an ever-mounting death toll - all of which were met by little response from the capital. Thus, when the Second Congo War (also known as the 
Great African War or the African World War) began in August 1998, it amounted to a continuation of the same conflict in the eyes of people living in the east of Congo. The Second Congo War (August 1998 to July 2003) saw the assassination of President Laurent Kabila (January 2001), the subsequent inauguration of his son Joseph Kabila (2001) and the establishment of a transitional government (2003). This was the deadliest conflict since the Second World War, claiming over 6 million lives.

Throughout the duration of this conflict, civil society initiatives played a strong role in advocating democracy and denouncing the corruption and illicit activities that fueled the violence. Political scientist Georges NzongolaNtalaja has argued that one main objective of this advocacy has been to counter the "myth that what was going on in the Great Lakes region was a civil [or ethnic] war" (Nzongola-Ntalaja, 2002, p. 232). As long as these conflicts are defined as "ethnic," there is less justification for international action: as such, the term "gave comfort to the aggressors and excuse for inaction by those responsible for upholding international peace and security, particularly the United Nations Security Council" (Nzongola-Ntalaja, 2002, p. 232). Consequently, the concentrated efforts by nonviolent civil society groups in the east of Congo and throughout the global Congolese diaspora aimed simultaneously (a) to bring awareness to the economic motivations of the conflict, and (b) to advocate the implementation of democratic policies and governing bodies who could oversee the disarmament of the ongoing conflict and establish viable national institutions.

While these civil society initiatives warrant much praise for their accomplishments, courage and perseverance in the face of violence (Nzongola-Ntalaja, 2002, pp. 241-245), the focus of their efforts on larger-scale issues left a significant void regarding the daily activities of the majority of the local population. Indeed, much civil society activity took place abroad in peace-building lobbies organized elsewhere (Switzerland, Belgium, Canada, France and Benin), which precluded the participation of local Congolese. Furthermore, the majority of these activities only peripherally included youth, who make up an ever-increasing percentage of the population given the loss of older generations in the war. Finally, as the efforts of civil society groups were repeatedly compromised by powerful international corporate and political interest groups, by the end of the millennium, conditions in the region had steadily worsened (Nzongola-Ntalaja, 2002, p. 263).

It was in this context that Yole!Africa was founded. It was conceived as an organization specifically directed towards youth populations, whose lives had been so largely defined by an ethos of violence, state collapse and the resultant erosion of institutions of learning and culture. ${ }^{10}$ The primary goals of the organization are (a) to provide a space for nonviolent self-expression despite ethnic, linguistic, religious, economic or gender difference, and (b) to develop in youth the capacity for critical thought. These founding principles align with Frantz Fanon's assertion that "[b]y imparting new meaning and dynamism to artisanship, dance, music, literature ... the colonized subject restructures his own perception" (Fanon, 1961, p. 176).

Yole!Africa is a nonprofit cultural center that provides both a physical space for and training in expressive practices, including music, digital arts, journalism, computer literacy, dance and visual arts. To this end the organization offers on-going workshops, one-time special events, an annual film and arts festival, as well as community gatherings such as seminars, performances, screenings and discussion groups. ${ }^{11}$ In addition, Yole!Africa 
than immediate - solutions. This stands in opposition to many nongovernmental organizations (NGOs) in the area that prioritize short-term responses to perceived emergencies in North Kivu. ${ }^{15}$ In contrast, Yole!Africa maintains that, even in the face of conflict and war, long-term strategies are essential if Congo is ever going to be successfully governed by Congolese and not continue to be controlled by neo-colonial relationships with the West. Central to this policy is Yole!Africa's assertion that basic human rights extend beyond immediate physical needs such as food, water and shelter to other elements of human experience, including:

intellectual and emotional autonomy, [conditions that foster] self-confidence, analytical skills and the ability to think and take critical distance with one's own reality, development of creative potential, the ability to transform traumatic experiences and release them, an attitude geared towards positive thinking and the creation of one's own destiny."16

This idea aligns with the theory developed by economist Manfred Max-Neef, who contended that there are nine basic human needs (subsistence, freedom, protection, affection, participation, understanding, leisure, creativity and identity), which are nonhierarchical and constant across time and cultures (Max-Neef, 1991, p. 17). Max-Neef advocated the idea that protecting human rights means creating conditions in which people's capacity to meet these basic needs is not systematically undermined through abuses of power such as oppression, totalitarianism, exploitation, prejudice or other social ills. In this light, Yole!Africa's emphasis on developing critical thought and nonviolent self-expression transects the fundamental needs of freedom, understanding, participation, creativity and identity. It is in this context that I suggest that the organization's commitment to supporting the agency necessary for people themselves to meet these needs (rather than an external organization meeting them) actually advances a sustainable human rights agenda because it promotes genuine individual transformative learning.

Yole!Africa's strategy for fostering self-esteem, confidence, and trust "promotes dialogue and respect for others and ... generates, through debate and reflection on current social and political issues, the awareness that everyone is an actor of his/her life and of the society in which he/she lives and has the right and duty to transform it for a better world" (Yole!Africa Project Description, 2000, P. 2). Many young artists who receive their training at Yole!Africa cite this "awareness" directly, and indicate that, for them, what they learn at Yole!Africa has less to do with choreographies, melodies or film editing techniques, and is instead a recognition of their capacity to effect their own reality. ${ }^{17}$ This recognition becomes fundamental and internalized component of their self-conception and remains with them far beyond the physical space of Yole!Africa.

Beyond fostering agency, Yole!Africa also recognizes that prolonged conditions of violence, war and trauma can rob youth of the ability to imagine a better future for themselves; therefore Yole!Africa's ideology also encourages youth to dream, to aspire to great things. This is evident in the amendment to the center's Kiswahili slogan: musingi yaku jichapia ndoto (the base from which to draw your own dreams), ${ }^{18}$ which serves as a reminder to the community that there is more to achieving peace than the signing of treaties and reaffirms the continued need for cultural development despite the official "ending" of the war.

However, these sentiments are not unmitigated by equal expressions of frustration, 
particularly on the part of youth whose efforts towards artistic achievement had little social capital or venue for promotion and development at the time. In its founding years Yole!Africa encountered much skepticism on the part of youth, who were facing the choice between the temporarily lucrative option of joining corrupt militia units, seeking refugee status that would allow them to travel to the West, or investing themselves in developing an artistic talent. This skepticism was profoundly enhanced by the repeated disintegration of peace talks and breaching of treaties between governmental and rebel bodies.

Indeed creating a space in this fragmented community to explore the role of culture in the face of life or death was not always successful. Yole!Africa's efforts were undermined by the international narrative of ethnic conflict as the root of the ongoing violence. In this environment, for youth - and their families - to support interethnic collaboration through creativity was deeply radical. Consequently, as an organization, Yole! Africa had to adapt and develop alternative strategies in response both to the ongoing physical threats of violence and to local skepticism. Over time, these strategies have evolved to include lucrative employment opportunities that grow out of the skill sets developed at Yole!Africa (such as film production, computer literacy and journalism). These strategies also reflect the agility of Yole!Africa, which, as a local organization, is able to meet ever changing local needs.

\section{The BIRTh OF SKIFF (2006)}

One of Yole!Africa's primary approaches to validating the role of culture in the face of ongoing conflict was to develop curatorial and exhibition strategies that would counter the exclusively negative international media focus on the region. Therefore, in addition to the earlier practice of exporting, exhibiting and selling youth art products, in 2006, Yole!Africa established SKIFF, the first international film festival in the DRC. In addition to providing a platform for artistic exposure, SKIFF also aimed to promote unity in the face of the increased national fragmentation and ethnic animosity perpetuated by the transitional government (2002-2006). SKIFF is an independent festival that promotes digital film and video arts as well as dance and music. SKIFF began as a guerilla festival - its first iteration played on in spite of advancing rebel attacks and served as an active cultural/artistic intervention in the midst of locally and internationally driven narratives of insurmountable ethnic savagery and war.

The establishment of SKIFF was, in the face of such unrest, a radically optimistic artistic event with profound political implications. The first festival brought together 6,000 people, demonstrating demand for and interest in largescale creative events in the east of Congo. Furthermore, the audience included members of various ethnicities, economic classes and religious groups, and brought together new voices for this heterogeneous audience to debate the role of arts within the larger community.

The 10-day festival includes film screenings, which are followed by community discussions, live concerts, a very popular dance competition, and a series of workshops led by local, regional and international artists and technicians. ${ }^{19}$ The run-up to the festival now includes educational events, where Yole!Africa screens films and hosts discussions in local middle schools, high schools and universities; workshops after the festival are another facet and opportunity for public conversation.

As a project of Yole!Africa, there is also an ideological objective to SKIFF that includes engaging the larger community in critical thought, catalyzing reflection and action, and 
bringing positive international attention to the region. Among the festival's objectives are "to professionalize and promote cinema and arts in the sub-region as well as to provide entertainment and a space for social life in this city [Goma] living under the threat of an ongoing conflict" (SKIFF Project Proposal, 2009, p. 1). Past themes include:

- 2006: Salaam en Pélicule (Peace Through Film). The first edition was organized around the central value of the festival: promoting peace. SKIFF 2006 offered the community an alternative forum for coming together and seeking solutions to conflict.

- 2007: Unity dans la Diversité (Unity Through Diversity). This edition challenged the general misconception of the conflict as an ethnic war and encouraged people to reframe their understanding of ethnic diversity as a source of strength and community cohesion.

- 2008: Sherehe ya uwasiliano (Celebrate Peace). This edition aimed to make discussions of peace a celebratory event rather than a bureaucratic process, and aimed to engage youth in substantive ways in the promotion of peace in the region.

- 2009: Kumbuka Kwaku Kumbuka Kuto Kusaharu Salaam Kivu (Remember to Remember Not to Forget about Peace in Kivu). This slogan refers to the then recent election of President Joseph Kabila, which took place in a general environment of hopeful anticipation of the peace and structural improvements he had promised in his campaign.

- 2010: Kawaida Baadaye/Saisir l'avenir (Seize the future). In commemoration of the 50th anniversary of DRCongo's independence from Belgium, this edition focused on understanding Congo's past and present in order to place youth as social actors capable of seizing the future.
- 2011: Votez Utile! (Cast your vote wisely!). In preparation for the 2011 elections (which took place one month after the conclusion of the festival), this theme was designed to foment discussion about the relationship between individual agency and democracy, and ultimately to encourage the community to take a more active stance in securing democracy rather than being bribed by politicians.

- 2012: Ni Wakati! (The Time is Now!). This edition aimed to concretize strategies of agency and civil society action after having reflected on the past 50 years, and the relationship between individuals and successful democracy.

As noted above, by organizing screenings, debates and activities thematically, SKIFF aims to promote critical thought and communication within the community. For example, Petna Ndaliko's short film Intervention Rapide (2008) follows the local police, showing elements of good will and sincerity in their efforts as well as offering critical perspective on their struggles with competing branches of law enforcement, the UN and deep-rooted internal corruption. The political climate during SKIFF 2008 rendered the screening of this film particularly timely, as fighting in the region was rife, and tension between the population, rebel militias and law enforcement was running high. In this environment, the popular perception of the police was as a menacing and corrupt force, aloof and unaccountable to the population it was meant to serve.

Following the screening, SKIFF organized a debate with Ngoy Sengelwa Kyo, North Kivu's Chief of Police at the time. The public debate was mediated by Benx Katonj Mubingwa, the premier news journalist for the national radio and television station RTNC, and by the filmmaker Petna Ndaliko. This was an unprecedented space for the community to engage in public dialogue with the 
police force. The aim was not only to bring about a public conversation, but also to demystify authority figures more broadly - a strategy intended as "the first step towards critical thinking." ${ }^{20}$ According to Ndaliko,

in Congo, powerful figures and representatives of authority, like the Chief of Police, are usually seen either on TV, or hidden in motorcades with numerous escorts and armed guards. People only see these figures when they are campaigning for votes, but as soon as they get elected, they start moving in cars with tinted windows where nobody can see them. Therefore people start believing they are fictional, that they are no longer human beings ... or that they have something to hide. But at SKIFF, [Sengelwa] came in plain clothes and left his uniformed police bodyguards in the car (he entered with one plain clothes body guard) which started to break down the wall between a fictional and mystified world and people's everyday human realities. $^{21}$

During the conversation itself, the community was able to pose challenging - and at times accusatory - questions to Sengelwa, many of which revolved around police corruption, and the use of police force during otherwise nonviolent public demonstrations. While this conversation clearly did not completely transform the relationship between the community and the police, participants indicate that there was indeed a perceptible increase in the understanding of the crowd as Sengelwa iterated specific challenges facing the police force in its process of internal restructuring. ${ }^{22}$ Furthermore, without promising immediate or complete reform, Sengelwa extended a request to the community that they report instances of corruption and substantiate their claims with proof in order to facilitate the efforts of those authorities sincerely working towards improving the police force. Sengelwa's invitation was received as genuine by the community, who prior to this debate had never had the opportunity to air their grievances to an authority in such a forum. Although it only represents a single step, this conversation exposed the humanity of a figure who was previously perceived as fictional and, as such, became a point of entry for further communication.

While the benefits of promoting art, culture and community regeneration in conflict regions are clear, there are also substantial risks. One of the more overt examples of the risks took place at the same edition in October 2008 when the region was under attack by rebel militias. Shortly before the scheduled opening of SKIFF, rebel leader Laurent Nkunda ${ }^{23}$ announced that he was going to seize Goma to secure control of North Kivu. SKIFF organizers decided that, under the increased threat of violence and terror, the need for the festival as a source of nonviolent opposition and an indication of the growing strength and hope of the community was, in fact, exponentially increased. Thus, despite real and immediate threats of violence, more than 9,000 people participated in SKIFF 2008. While the spectacle of people potentially endangering their lives to participate in a film festival is perhaps surprising, framed in the context of the "film act" of revolutionary or Third Cinema practices, in which the viewer is "no longer a spectator [but] ... from the moment he decide[s] to attend the showing ... by taking risks and contributing his living experience ... [becomes] an actor, a more important protagonist than those who appear in the films" (Solanas and Getino, 1969, p. 16), participation in SKIFF provides a window into a 
community whose engagement with cinema is transforming them into agents of social change. In this context, the spontaneous chant - hatutaki ma click, click/tuna penda ma kiss, kiss/juuya peace, peace $^{24}$ - that broke out among the crowd at the 2008 dance competition as rebels advanced within $5 \mathrm{~km}$ of the city and tanks and trucks full of soldiers moved through the streets, indeed established the spectators as protagonists and agents in an unfolding narrative.

One critical aspect of SKIFF's operational strategy is the effort to maintain financial autonomy as a means of ensuring ideological and operational independence. In the early years, Yole! Africa organized the festival activities, provided venues and equipment and Alkebu Film Productions, the commercial production house founded by Petna Ndaliko, funded the festival. ${ }^{25}$ As SKIFF grew, it drew a number of international funders eager to support the festival's civic aims. ${ }^{26}$ Despite evident financial need SKIFF has always refused partnerships from organizations who required counterpromotions, such as hosting special events for rape victims, former child soldiers or HIV-positive youth during the festival. While Yole!Africa has always invited these community members in all activities, the organization believes that targeted events such as these draw negative attention to those concerned, bringing even more stigma to them rather than working towards holistic integration in the community. By refusing to classify participants according to illness or trauma, SKIFF aims to directly counter outsiders' more pessimistic expectations of the east of Congo. Negotiations between SKIFF and potential funders indeed have become a new avenue through which the festival promotes its ideology of independence and agency. As a result of dialogues initiated by SKIFF organizers, who advocate a more diverse representational strategy as a means of supporting local achievement, a number of influential funders have ultimately revised their funding policies for the region. ${ }^{27}$

\section{The NYAVU Network}

By 2009, Yole!Africa had made a significant impact on youth, on local civil society initiatives in North Kivu and in the international arts world. ${ }^{28}$ The center was thriving as youth became increasingly invested in expressive culture having seen both how it improved the lives of their local peers and the growing potential for professional careers. However, with regional violence increasing, particularly through invasions by neighboring countries Rwanda and Uganda, tension in North Kivu was still quite high. Thus, in a roundtable discussion during SKIFF 2009, a group of artists analyzing the political situation in the Great Lakes region expressed interest in establishing a network that would allow for a cultural critique of the conflict and a platform upon which to magnify their individual efforts through collective organization. The artists' recognition of this need led to the founding of the NYAVU network, which Yole!Africa organized in late 2009.

NYAVU includes artist-activist organizations from seven Great Lakes and eastern African countries $^{29}$ and is predicated on two key premises. The first is that regional rather than national solidarity is essential in order to resolve the conflict. The second is the view that this long-standing conflict is not at its roots ethnic, but rather economic, reflecting multinational corporate demand for mineral resources. Accordingly, NYAVU curates regional performances and cultural exchanges based on the understanding that successful artistic interventions within economically driven conflicts require strategic regional in addition to national - exchanges.

This network was founded at a time when there was an increasingly palpable influence in 


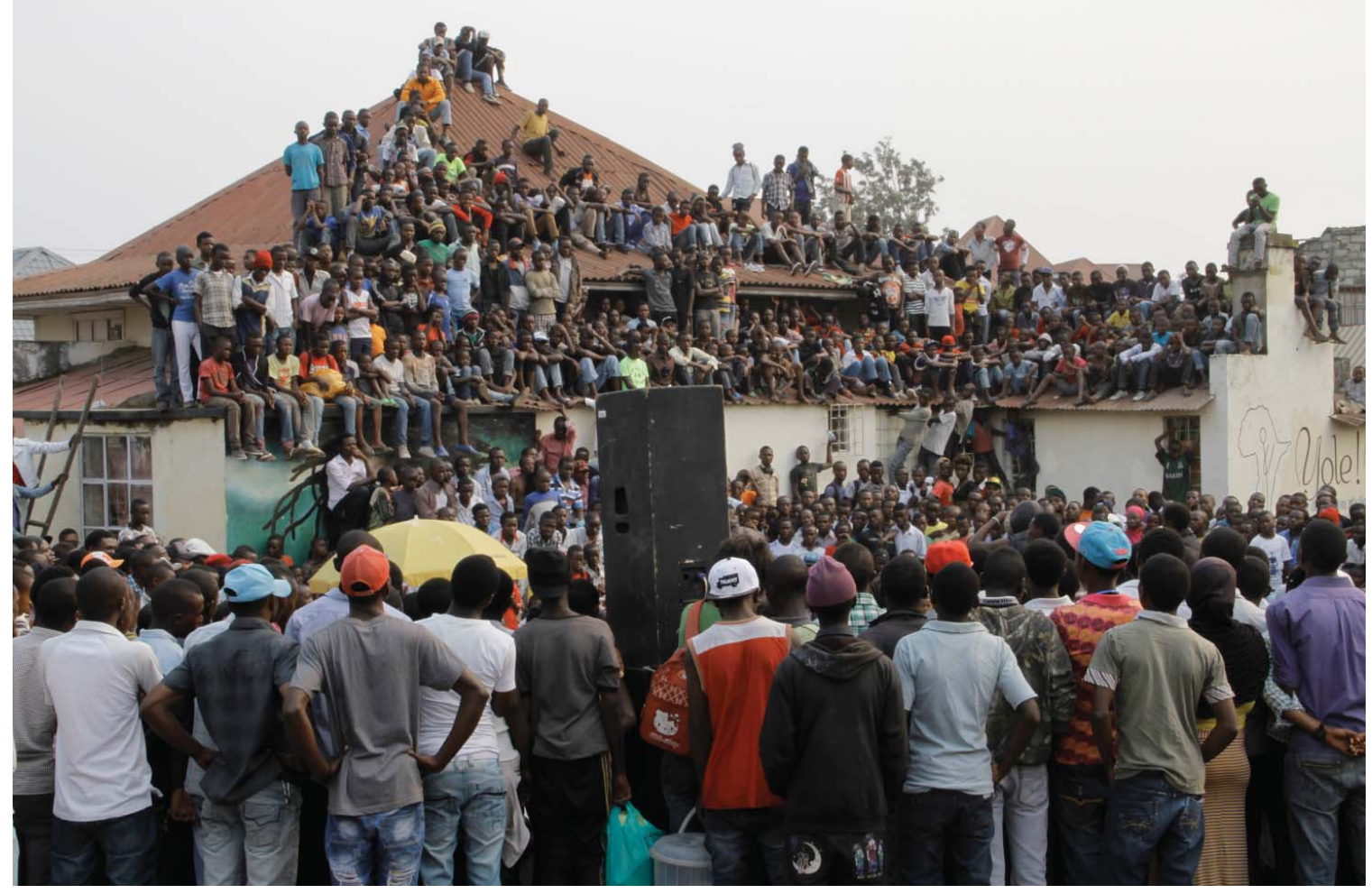

Figure 3. Yole!Africa compound during Jam Session. Courtesy of Alkebu Film Productions.

Permission to publish granted by Alkebu Film Productions.

the Great Lakes region of globally powerful nations such as China and Brazil, who were actively creating economic allegiances with mineral-rich Congo. While such allegiances did not necessarily represent a particularly immediate cultural influence (especially in the case of China), participants in the more commercialized areas of artistic production were clearly aware that positive alliances with wealthy international investors could be quite lucrative (if to a lesser degree) for artists as well as for the mining sector. Thus NYAVU's explicit focus on exposing the economic motivations for the conflict was a considerably radical stance and indicates two central objectives of the politics of this new network - namely to maintain financial autonomy and artistic control especially in situations where both of these are undermined by the very institutions which in theory might support them.

The need for financial autonomy in North Kivu is underlined by the influx of humanitarian organizations and international NGOs responding to the crisis. Apropos here is James Ferguson's critique of "transnational entities", which he claims both overlap with and undermine governmental bodies, even while they set out with humanitarian agendas. He suggests that it is 
"necessary to devote some critical scrutiny to the common-sense mapping of political and social space that the state-civil society opposition takes for granted" (Ferguson, 2006, p. 90). The east of Congo presently hosts an increasingly powerful group of transnational organizations that inhabit a space distinct from both government and local initiatives while at the same time exerting (not altogether positive) ideological and economic pressure on them.

Since 1994, there has been an influx of humanitarian organizations to North Kivu who aim to provide relief to local people suffering owing to persistent regional conflict. Many of these aid and NGO operations eventually launch cultural initiatives and collaborations to increase visibility and popularity. However, budget restrictions and social objectives outlined for these organizations require very specific criteria and control over arts and cultural initiatives. It comes as no surprise then that the resulting projects are didactic, extremely conservative or emphasize sales and fundraising over the interests and demands of local audiences.

One example suffices to illustrate the heavyhandedness of this NGO-patronage approach. As a project of art therapy for "recovering" child soldiers, one Goma-based NGO created an art competition, in which children's paintings were selected for auction in Europe, the funds from which would contribute to their school fees. The paintings were nominated for selection based on criteria of violence, as drawing depictions of violence was equated with processing trauma. In an ideological stance reminiscent of remorseful colonialists who "likened ... scathing denunciations, outpourings of misery, and heated words to an act of catharsis" (Fanon, 1961, p. 173) paintings of explosions, guns, fighting, death, etc., were considered the most therapeutic and therefore held in high regard, whereas images of family scenes and depictions of friendship earned less recognition, regardless of the caliber of the artistic work. The children very quickly learned that, according to buyers, art production was directly related to their ability to represent themselves (and imbed themselves artistically) as victims of violence. ${ }^{30}$ While there is financial evidence to support the claims that this project, and others like it, was a success (school fees were indeed paid), this instrumentalist approach was bound to construct perverse lessons for the artists. The commodification of suffering is a recurrent and destructive theme in many misguided formulations of international arts and culture patronage.

NYAVU network members are diametrically opposed to such commodification. In contrast, the network draws in members of the community, particularly youth, fosters development by encouraging people to advance and professionalize their artistic skills. NYAVU's policy focuses its energies on making available tools and space for development, rather than promoting particular artists or didactic productions. This distinguishes the network, and even puts it at odds with most international organizations present in the region. NYAVU's policy has created deeprooted tensions with some North Kivu artists, who have protested the efforts of the local organizations. Their complaints are fueled by their perception that local organizations should promote artists based on the criteria established by NGOs (such as the child soldier art therapy project) rather than "artistic merit". 31 This tension indicates the degree to which evaluations of artistic capacity based on the overdetermined subjects of violence and suffering are in fact fully integrated into the communal understanding of artistic "talent." It has also become clear that, for many in North Kivu, the role of a cultural center is unfortunately now conflated with the work of an NGO. 
Despite Yole!Africa and the other NYAVU members' open opposition to economically motivated artistic interventions in the region, because of their success there is increasing economic pressure for network partners to collaborate with humanitarian organizations. NGOs routinely tout their collaboration with NYAVU as evidence of their local engagement. Thus the NYAVU imprimatur has become a vector of authenticity and progressiveness for international NGOs, although in some cases this has cost its member organizations somewhat in their prized local reputations as radical arts organizations. The claims advertised by the NGOs tend to distort the work of local partners, for example calling an arts center a place of healing because of the inclusion of former soldiers. While the network invites all comers, singling out former child soldiers to buttress statistical evidence conflicts with NYAVU's emphasis on integration without stigmatization. A similar example is evident in the participation of young women who are survivors of sexual violence. There are numerous NGOs in the Great Lakes region dedicated to helping these women, yet, perhaps unintentionally, they risk victimizing the women in a different way by presenting them as victims of rape as opposed to human beings with names, identities and aspirations. The successful engagement of numerous NYAVU member organizations with these young women and with child soldiers is well recognized locally and internationally, yet it is perhaps this very success that encourages distorted international representation.

All of these symptoms of representational imbalance underscore the importance of regional collaborations that allow organizations, such as those that form the basis of the NYAVU network, to maintain financial autonomy and not co-opt their artistic and curatorial choices for the sake of funders' demands. The NYAVU network's successes are apparent in garnering sizable grants that make regional exchange possible, and exceed the support any individual organization would receive. All of this has allowed member organizations to significantly magnify their impact.

In short, cultural networks are critically important as they allow artists working towards sustained peace in the Great Lakes region to unify their efforts. Not only do networks provide routes along which films, songs, dance pieces and visual arts can travel, but they also enforce an environment of exchange that facilitates collaboration beyond national boundaries. This inter-regional collaboration and co-creation is an essential counter-strategy to those local and national governments, rebel groups and insurgents who attempt to control the region through division and segregation.

\section{The Jazz Mama Movement}

By 2009 Yole!Africa had successfully created an alternative to violence and dependence for local youth; however, the ratio of male to female participants was 4:1. Meanwhile, international narratives continued to perpetuate ominous and flat sound-bites, that the east of Congo was "the worst place in the world to be a woman or a girl" (Friends of the Congo, 2011, 0:08:39). Without in any way minimizing the devastation of sexual violence as a weapon of war in the ongoing conflict, Yole!Africa became increasingly invested in intervening in this narrative from a local perspective and launched the Jazz Mama Movement in 2010. Jazz Mama hoped to present deeper possibilities for how girls and women can contribute different voices.

Before examining the specifics of the Jazz Mama movement, it is important to contextualize rape and sexual violence in the east of Congo. Gender-based violence has proven to be 
the least expensive and most thoroughly destructive weapon in the conflict for Congo's mineral wealth. ${ }^{32}$ In 2009 Doctors Without Borders published a report stating that " 75 percent of all the rape cases [they] dealt with worldwide were in the eastern Congo" (Grignon, 2009); indeed since then the situation has deteriorated to the extent that high estimates place the number of women raped on a daily basis between 80 and 130, claiming even this as only a fraction of the totality as so many rapes go unreported owing to shame and social stigma (Goodwin, n.d.).

The scope of problems brought on by this epidemic - including the increased transmission of HIV/AIDS, unwanted pregnancies, fistulas, not to mention trauma, stigma and shame - is monumental and warrants the highest degree of national and international outrage and intervention. Yet local wisdom suggests that, precisely because sexual violence is such a devastating and emotional aspect of the crisis, it is particularly important to consider the ways in which it is mediated. Indeed, representations of the problem and the people involved significantly shape global strategies employed by those humanitarian and governmental agencies working to bring an end to this crisis.

It is in this context that the Jazz Mama movement offers an artistic intervention. Specifically, the movement aims

to bring awareness to gender based violence in Congo without reducing the women to victims whose lives are circumscribed by rape, but instead to recognize that, while sexual violence is indeed a devastating problem, these women are often not only survivors but the pillars of the community. ${ }^{33}$
From this spun a number of new initiatives. The Kivu Choir began as a means of encouraging the participation of more women and girls in Yole!Africa's activities. ${ }^{34}$ In addition to singing traditional songs, the choir began to sing live vocal soundtracks which added a new dimension during projections of local films. This project allowed women to actively give voice - in the most literal sense - to the images representing their community. As the choir grew more popular, the film component grew alongside it. The second Jazz Mama activity was to train young women to make short films that center on the daily activities of women and girls in the region. ${ }^{35}$ Over six-month periods, the three best films were selected monthly and premiered together in a public screening and concert event. ${ }^{36}$ Films of the Kivu Choir performances and the student films culminated in the international 2011 Jazz Mama tour. ${ }^{37}$

From a local perspective, these projects profoundly shape the discourse of gender in the east of Congo. First, they allow women and girls as members of the local community to tell their own stories on their terms rather than being represented as victims or subjects by dominant media outlets. As sexual violence in Congo receives increasing international attention, there is a real danger that the people whose lives are shaped by this crisis do not have access to the means with which to represent their own stories. Consequently, modes of humanitarian intervention do not always reflect the real needs of local communities. Projects like the Kivu Choir and the Jazz Mama short film series aim to expand such international dialogues to include the voices of the women and men who experience these acts of violence so that their perspectives can contribute to shaping applications of international aid.

In addition to including local voices, the Jazz Mama initiative also introduces multiple 


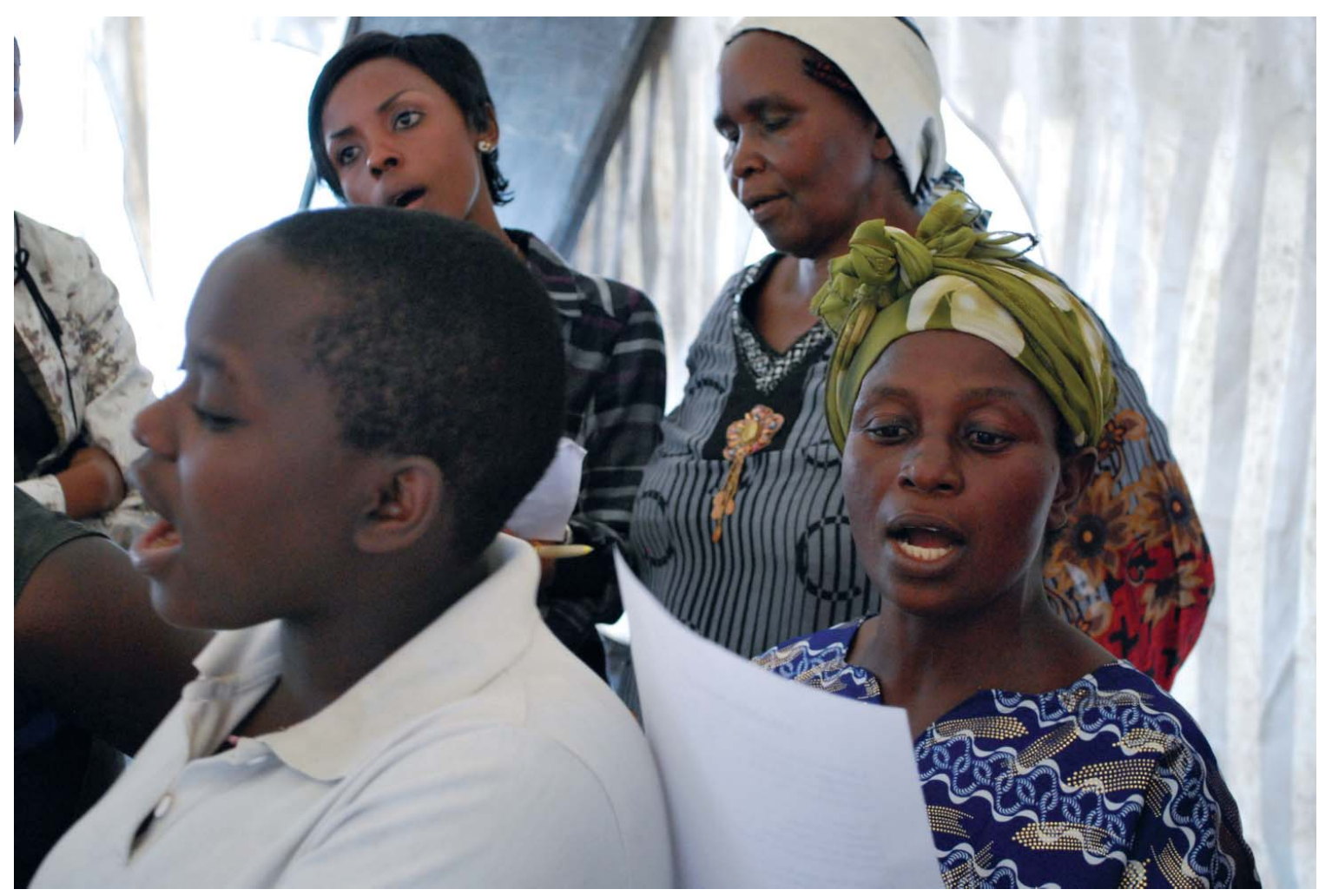

Figure 4. Kivu Choir rehearsing at Yole!Africa 2010. Courtesy of Alkebu Film Productions.

Permission to publish granted by Alkebu Film Productions.

dimensions into discussions of gender, which otherwise risk eliding the fact of repeated sexual violence with the misconception that such violence reflects a lack of respect for women in Congolese culture. Although subtle, this distinction is crucial and once again brings some methods of humanitarian intervention into question. Specifically, interventions based on an ethnic interpretation of the conflict frame the perpetrators of rape as savage and lust-driven, whereas economic interpretations of the conflict recognize that the prevalence of rape is a direct reflection of longheld centrality of women in Congolese societies.
In short, in cultures in which women play central and defining roles, the destruction of the female body is the most efficient means of destroying the collective. By introducing contextualized portraits of Congolese women, young people have the opportunity to represent their reality and to educate the global population. While this is clearly only one step in the larger project of bringing an end to the rampant sexual violence in the region, participants in the Jazz Mama movement express an increased sense of empowerment as a result of their ability to participate in a global dialogue as agents rather than as de facto victims. 


\section{Conclusion}

In celebration of its tenth anniversary, Yole! Africa curated a number of events that trigger reflection on the impacts of the organization's first decade of existence in the region. In addition to performances and installations, these events include dialogues with many former Yole!Africa participants who have gone on to establish successful careers - both locally and internationally - in fields such as law, politics, commerce, computer engineering, journalism and arts. The tenth anniversary activities have garnered national and international media attention, which has recognized Yole!Africa as a regional pioneer and acknowledged the power of creative expression to effect positive social and political change. ${ }^{38}$ Such validation suggests a growing appreciation for the center's success.

At the same time, the invasion of the M23 army, which occupies Goma at the time of writing, poses the next in a long line of threats against the stability in the region and will consequently push Yole!Africa to continue to reinvent many of its strategies. At this pivotal juncture, the organization continues to respond to the immediate political and economic implications of this situation, providing specific platforms for expressive action and reflection in response to an environment of escalated violence. In short, Yole!Africa is keen to improve its activities in line with the important lessons learned over the past decade. Indeed, in this region in which the only constant has been change and upheaval, continued success is not a given, but rather can only be a reflection of a continued commitment to foundational principles that are themselves flexible. Throughout this essay I have argued that, by cultivating a sense of empowerment and agency among marginalized segments of the population, arts organizations such as Yole!Africa can shift the collective understanding of the relationship between cause and effect, and between individuals in society and the potential for civil intervention. However, the success of this initiative in the face of the most recent threats remains to be seen.

Thus, while specific examples of Yole!Africa's activities are indeed compelling, this portrait would not be complete without addressing an evident underlying question, namely, why support art and culture as the means of intervention or, more specifically, why opt to invest in artistic expression when people's physical safety is under threat? As artists and activists, the organizers assert the transformative aspects of art in the midst of conflict. In the Great Lakes region, where so much is contested, art is the one domain that has the power to transcend language, ethnicity, economic status, gender and religion; it consequently allows people to forge new social pathways and vivid personal connections. From these new ties and inspirations, we hope, will come new choices and ultimately new patterns of behavior. When such behavioral shifts are based on critical thought and reflective action rather than rote perpetuations of violence, they have the potential to effect tangible change.

Yole!Africa's efforts bear in mind Freire's assertion: that " $[\mathrm{i}] \mathrm{n}$ dialectical thought, world and action are intimately interdependent. But action is human only when it is not merely an occupation but also a preoccupation, that is, when it is not dichotomized from reflection" (Freire, 2007, p. 8). Yole!Africa's efforts to unite action and reflection provide a foundation focused on dialectical thought and agency in communities that have been paralyzed by fear, corruption and internationally determined aid programs. In this light, despite challenges, Yole! Africa's engagement with expressive culture is in fact a profound engagement with what is deeply 
human in a region too often reduced to its international monetary value. All of this cannot help but compel us to continue to invest in art in the face of violence, and in the radical artistic interventions that play a crucial role in local, regional and international transformation.

\section{Notes}

Chérie Rivers Ndaliko (ndaliko@unc.edu) is an assistant professor in the Music Department at the University of North Carolina at Chapel Hill. Her research interests center on radical arts interventions in conflict regions of Africa. She has conducted research in many African countries on the potential of film and music to contribute to movements of positive sociopolitical transformation. Her particularly region of focus is the east of the Democratic Republic of the Congo, where she has lived and worked for many years. She is also a composer and pianist who holds a BM in film scoring from the Berklee College of Music, an AM from Harvard University in Ethnomusicology, and a $\mathrm{PhD}$ from Harvard University in African Studies. In addition to her teaching and research, she also serves as codirector of the Yole!Africa cultural center in Goma, executive director of the Salaam Kivu International Film Festival and faculty advisory for Yole!Africa US.

1 This event was also part of the tenth anniversary celebration of Yole!Africa.

2 Participation in Yole!Africa's activities grew from about 200 in 2002 to over 24,000 in 2012, with funding and international recognition of its regional impact in the region increasing over the decade.

3 DRC is the twelfth largest country in the world by area (3.8 times larger than France).

4 Under the RCD movement (1999-2002), during which rebels fighting against President Laurent Kabila controlled the east of Congo, it was not possible to fly from anywhere in eastern Congo to Kinshasa. The travel routes were via Nairobi to Kinshasa. Currently it is possible to fly directly from eastern Congo to Kinshasa; however, there is no way to travel by road and the cost of a roundtrip air ticket is approximately US\$800-1000 as compared with a US\$5-20 bus ticket to travel to Rwanda, Burundi or Uganda.

5 The exceptions to this are the national finals hosted in Kinshasa for many of the cultural competitions such as Vodacom Super Star (national singing competition) and Kata Dance (a national dance competition).

6 For example SESAM (organized by a French enterprise), Rencontre Chorégraphique (organized by a Belgian enterprise), and the Goethe Institute. Most European and American Embassies have cultural divisions funding activities in Kinshasa.

7 For example, Heal Africa Hospital recorded a music album in 2008; Search for Common Ground and the Red Cross curate theatre and film projections; Solidarité organizes concerts; and the UN World Food Programme has hosted various poetry and musical events.

8 For a thorough account of this conflict see Nzongola-Ntalaja (2002).

9 Coltan, which is a composite of tantalite and cassiterite, conducts electricity without heating up and is therefore essential to many personal electronic devices including cell phones, laptop computers, digital cameras and pace makers, as well as larger industrial products in the aviation, automobile and weapons industries. At least 64 percent of the world's known coltan repositories are in the east of Congo.

These conditions were further exacerbated in Goma by the eruption in January 2002 of Volcano Nyiragongo, which destroyed over 30 percent of the city.

11 The on-going workshops include: film and video production and editing; music performance and production; contemporary, hip hop and break dance; painting, visual arts and photography; writing and blogging; computer literacy. Special events include: master classes and intensive seminars (ranging from 5 days to 1 month) with accomplished musicians, filmmakers and dancers; artist residencies; and national and 
international media events. Community gatherings include specific programs such as: Ciné Club - a weekly screening of films open to the public and followed by a critical community debate; Ciné Mobile - a project that screens films in schools, hospitals and rural areas throughout North Kivu; Baraza - weekly debates on social/political topics, which falls within Yole!Africa's Cultural Exchange program; Jam Sessions - monthly public performance opportunities for local musicians that average 400-600 audience members.

12 Yole!Africa Project Description (2000), p. 5. The original project description is part of the organization's articles of incorporation and was written by Petna Ndaliko Katondolo and Ellen Lammers in 2000 in Kampala Uganda.

13 Nzongolo-Ntalaja, p. 243.

14 With regards to refugee services my research indicates that, in addition to those families who were in dire need of such services and support, a significant number of youth from North Kivu attempted (often successfully) to gain refugee status, not primarily because their lives were in danger, but rather as it was perceived as an effective means of traveling to the West and thereby elevating their status.

Many humanitarian organizations offer training to local populations in practical skills such as carpentry, masonry, mechanics and basket weaving based on the assertion that such training will help local people gain employment. However these trainings generally last only a couple of months and fail to address larger issues of post-training integration, specifically where the newly acquired skills might not fit with a person's inherited livelihood. Youth often complain that, having earned certificates from multiple trainings, they are still nowhere near able to compete with their peers who have learned these skills from an early age. Furthermore, in most programs there is no continuity between who learns which skill, which leaves many people whose families have been based in agriculture (for example) being thrown

into mechanics or an equally foreign field based on no choice of their own.

Workshops include: video production and editing (documentary, animation, feature and creative); music video creation; audio recording/ production and engineering; music composition and performance; poetry and storytelling; hiphop and contemporary dance; and Kivu Symphony, which was started at SKIFF 2010 and refers to a collaborative creative project between participants in a creative documentary film workshop and members of the Kivu Choir. In its final form, the choir performed a live vocal soundtrack to a short creative documentary filmed and produced by the students. The number of participants in each activity varies significantly from some very small workshops with no more than 12 people, to the pre-dance competition éliminatoire that regularly includes 180-230 dancers, to the large public concerts that draw crowds of 3000-4000, bringing the total spectator count to over 12,000 in 2010 and 13,000 in 2011. Over the years SKIFF has also increased the number of films screened from 10 (in 2006) to 32 (in the 2010 and 2011 editions). 
Interview, Petna Ndaliko Katondolo conducted on November 17, 2010 in Goma, DRC.

Ibid.

A specifically resonant point he offered was that the majority of the 'thieves and thugs' in the police force are former members of the military whose training substantially outranks that of even the national police, making systematic elimination of corruption and abuse of power a slow and cumbersome process.

Laurent Nkunda is a former general in DRC's armed forces, and was the renegade leader of one of the strongest rebel factions in North Kivu and the founder of the National Congress for the Defense of the People (CNDP) until has capture in early 2009. The threat referenced here refers to the '2008 Nord-Kivu Fighting,' which began on October 27, 2008.

Trans: we don't want click, click (referring to the cocking of a gun) we want kiss, kiss/for peace, peace!

Alkebu Film Productions is a private film production house founded by Petna Ndaliko, www. alkebu.org.

These funders include the American Cultural Center, the Spanish Embassy's Cultural Cooperation, Foundation DOEN (Dutch), SESAM (French), Both Ends, Baobab Connections, Afrika in the Picture Film Festival and Afrika Leuwen Film Festival.

For example, in September 2010, a prominent Dutch organization chose to restructure its funding requirements in order to collaborate with Yole! Africa's production of the fifth annual SKIFF.

Yole!Africa and the artists who received their training there are best known in South Africa, Uganda, Tanzania, Holland, Belgium, Sweden, Canada and the USA.

At the time of writing members of the NYAVU network include: Studio Kabako (DRC); Racines Alternatives (DRC); Yole!Africa (DRCongo); Mulika Trust (Kenya); Uganda Film Foundation (Uganda); DEDAC Film Productions (Uganda); Uganda Break Dance Project (Uganda); Kundayi Musanami (Zimbabwe); Africanhiphop.com
(Tanzania); Natti Dread International (Rwanda); and Baobab Connections (Burundi).

My sources for this information are interviews with 10 of the youth who participated as well as an interview with a former employee of this project, who indicated that these criteria were not presented in written form, but rather reflected the sentiments of those nominated to judge the artwork. This came up during a public meeting hosted by the Goma branch of Alliance Française on November 1, 2010.

32 Rebutting the attempted explanation that rape is a common occurrence in war zones, journalist Nicholas Kristof quotes former Canadian ambassador Stephen Lewis (who was the UN's envoy for AIDS in Africa) insisting that mass rape in the Congo conflict "has taken a new twist as commanders have used it as a strategy of war. There are two reasons for this. First, mass rape is very effective militarily. From the viewpoint of a militia, getting into a firefight is risky, so it's preferable to terrorize civilians sympathetic to a rival group and drive them away, depriving the rivals of support. Second, mass rape attracts less international scrutiny than piles of bodies do, because the issue is indelicate and the victims are usually too ashamed to speak up" (Kristof, 2008). www.jazzmama.org/themovement, accessed December 10, 2012. This is excerpted from the Mission Statement in the press kit of the Jazz Mama Movement, which was co-authored by myself and Petna Ndaliko Katondolo.

Because many of the youth at Yole!Africa are developing a hip-hop aesthetic, the more conservative families of women and girls were not as open to their daughters and wives participating. However, when the center launched a choir the response was much more favorable and drew many women and girls. Of the 22 participants in the original choir, 16 were women ranging in age from 16 to 68 . In many cases participation in the choir served as a point of entry into Yole! Africa's other activities. In the two years since the launch of the Kivu Choir the overall ration 
of male to female participants in Yole!Africa has shifted from 4:1 to 3:1.

The subjects of these films included: issues of beauty and physical presentation, ambitions and dreams of young women in North Kivu, the role of women in traditional healing and modern medicine, women and girls at work and at play and portraits of female innovators and activists. These short films were funded in collaboration with the Nike Foundation.

Local screenings attracted audiences of 300-450 people.

This tour included 33 colleges and universities in the USA as well as stops in South Africa, the Netherlands and Belgium.

See for example: Congo's Hidden Cultural Hub (http://www.theguardian.com/world/2013/mar/

13/congo-cultural-hub-goma, accessed December 10, 2012) and Artists in eastern Congo Operating Outside the NGO Realm (http://www. africanhiphop.com/featurestories/artists-ineastern-congo-operating-outside-the-ngo-realm/, accessed December 10, 2012). See also: Friends of the Congo, Qui a peur de Yole!Africa? (http:// humanitariannews.org/20120428/qui-peur-deyoleafrica, accessed December 10, 2012).

\section{REFERENCES}

Friends of the Congo (2011). Crisis in the Congo: Uncovering the truth.

Fanon, F. (1961). The wretched of the Earth. New York: Grove Press.
Ferguson, J. (2006). Global shadows: Africa in the neoliberal world order. Durham, NC: Duke University Press.

Freire, P. (2007). The pedagogy of the oppressed. New York: Continuum.

Goodwin, M. (n.d.). Can't blame colonialism for current rapes in Congo. Retrieved from http:// chronicle.com/blogs/brainstorm/cant-blamecolonialism-for-current-rapes-in-congo/37630

Grignon, F. (2009). Rape as a weapon of war in Congo. International Crisis Group, June 11. Retrieved from http://www.crisisgroup.org/en/ regions/africa/central-africa/dr-congo/rape-as-aweapon-of-war-in-congo.aspx

Jazz Mama Press Kit (n.d.). Retrieved from www. jazzmama.org/thefilm

Kivuila, C. (2002, June 5). Le SKIFF 2012. Events $R D C$ online. Retrieved from http://www. eventsrdc.com/?p=2326

Kristof, N.D. (2008, June 15). The weapon of rape. New York Times (op-ed).

Nzongola-Ntalaja, G. (1998). Revolution and counterrevolution in Africa: Essays in contemporary politics. London: Zed.

SKIFF 2009 Project Proposal.

Solanas, F. and Getino, O. (1969). Towards a Third Cinema. Tricontinental.

Stam, R. Eurocentrism, Afrocentrism, and polycentrism: Theories of Third Cinema. Quarterly Review of Film and Video, 13(1-3), 217-237.

Yole!Africa Project Description (2000). 